\title{
Effects of Ground, Concentrated, and Powdered Beef on the Quality of Noodle Products
}

\author{
Ki Hong Jeon*, Yoon Seon Hwang, Young Boong Kim, Eun Mi Kim, Jong Dae Park, and Jin Young Choi ${ }^{1}$ \\ Korea Food Research Institute, Sungnam 463-746, Korea \\ ${ }^{1}$ Division of Food Science and Culinary Arts, Shinhan University, Korea
}

\begin{abstract}
The aim of this study was to ascertain the effects of beef on the quality characteristics, such as color, texture profile, water absorption ratio, volume, turbidity, and sensory evaluation, of noodle products. Various types of beef were added to the flour at a mixture ratio of ground beef (BG) 10,15,20,25\%; concentrated beef (BC) 9, 11, 13, 15\%; and powdered beef (BP) 1, $3,5,7 \%$. Each treatment was analyzed and compared with a $100 \%$ flour noodle as a control. With increasing BG, BC, and $\mathrm{BP}$ ratios, the $\mathrm{L}$ and $\mathrm{b}$ values for color decreased, while the a value increased, from that in the control. The hardness of the noodles treated with BG increased with increasing mixture ratios, but hardness decreased in the BC and BP treatments with increasing mixture ratios $(p<0.05)$. The noodles with the largest beef composition in the mixtures of each treatment exhibited the highest turbidity scores, which was believed to be because the solid contents would be transferred to the soup during heating. In the sensory evaluation of cooked noodles, the BG 10\%, BC 9\%, and BP 1\% treatments exhibited the best color. In an overall preference test, $20 \%$ of $\mathrm{BG}$ and $3 \%$ of BP could be added to the noodles. The best palatability was exhibited by the $\mathrm{BG} 10 \%$, BC $13 \%$, and $\mathrm{BP} 3 \%$ treatments.
\end{abstract}

Keywords: ground beef, concentrated beef, powdered beef, quality, noodle

\section{Introduction}

Noodles are a very common food product. Since wheat flour was first introduced into Korea in the 1950s, many kinds of noodle products have been developed (Lee et al., 2000), and instant noodles account for a large proportion of the noodle market because they are easy and convenient to use (Lee and Kim, 2000).

Currently, various kinds of noodle products are being developed that meet the requirements of consumers who want healthier and better-tasting products. Consequently, the consumption of healthy noodle products, such as green tea, seaweed, cacti, gardenia fruits, etc. is increasing (Kim and Kim, 2009). However, these noodle products are based almost entirely on plant materials, and no noodle products that contain meat are on the market.

Rich, fatty animal parts, such as beef loins and ribs, are very popular in Korea because of their suitability for roasting. However, the low-fat-containing parts that are

\footnotetext{
*Corresponding author: Ki-Hong Jeon, Division of Platform Technology Research Group, Korea Food Research Institute, Sungnam 463-746, Korea. Tel: +82-31-780-9077, Fax: +82-31-7809876, E-mail: khjeon@kfri.re.kr
}

not good for roasting, such as beef round, are oversupplied because they are less in demand. Therefore, many researchers are attempting to balance demand and supply by developing popular processed-meat products.

Noodle products containing ground beef, concentrated beef, and powdered beef could be beneficial in terms of good nutrition. This study was conducted to develop fresh noodle products that contain over $20 \%$ meat, and that retain a good binding capacity.

\section{Materials and Methods}

\section{Preparation of materials}

The meat materials used in this experiment were ground (BG), concentrated (BC), and powdered beef (BP) from beef round. These were mixed with flour, salt, and water to prepare various types of beef-added noodle products. The Hanwoo round was purchased at the local mart in Bundang and was ground (Hand Blender, MR5550MCA Braun, Spain) to make BG. The remaining BG was freezedried (Ilshin FD5512, Ilshin, Korea) after deep freezing (VIP Series, Sanyo, Japan) for $48 \mathrm{~h}$. The freeze-dried beef powder was sieved through 20 meshes (Test sieve, 850 $\mu \mathrm{m}$; Korea) before being used for the noodles as BP. BC 


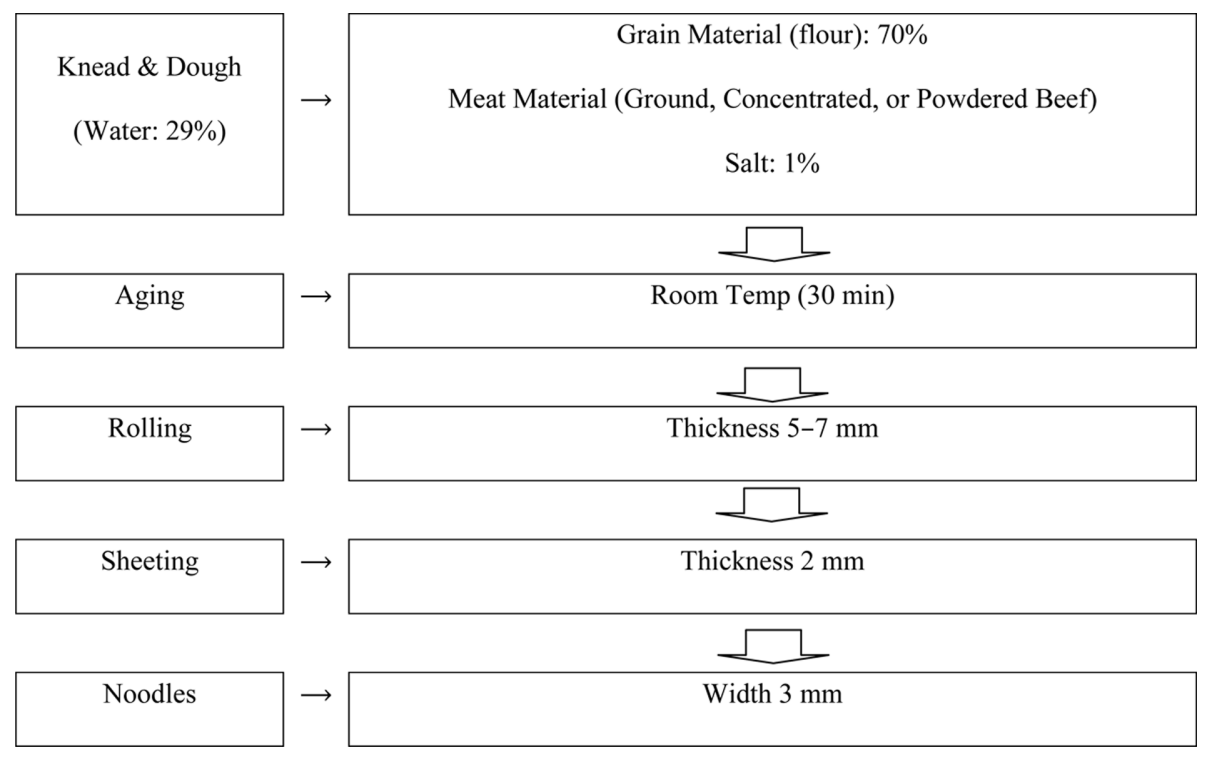

Fig. 1. Processing noodles made by mixing various types of beef.

was purchased from the $\mathrm{N}$ company. Wheat flour (Chalmilgaru, $\mathrm{C}$ company) and salt (Ggotsogeum, $\mathrm{T}$ company) were also bought at a local mart and used for noodle making.

\section{Manufacturing noodles added with meat}

The process of kneading dough mixed with flour, and various types of beef and noodle making, is shown in Fig. 1. As the various moisture and solid contents of the BG, $\mathrm{BC}$, and $\mathrm{BP}$ mixture ratios of each treatment changed, depending on the mixture ratio, to make up the moisture balance in the noodle. The formulations of the mixtures with $\mathrm{BG}, \mathrm{BC}, \mathrm{BP}$, and the other materials in the noodles are presented in Table 1. The mixtures were kneaded (KitchenAid, K5SS, USA) and aged for $30 \mathrm{~min}$ at room temperature. The kneaded dough was passed through a pasta roller (KitchenAid, K5SS 5957Adzw 707, USA) dozens of times until it had the same thickness $(2 \mathrm{~mm})$, and was then cut into the same width $(3 \mathrm{~mm})$ with a pasta cutter. Each noodle was cooked at $100^{\circ} \mathrm{C}$ for $3 \mathrm{~min}$ in a separate pot, and was washed with cold water for $30 \mathrm{~s}$ immediately after cooking.

\section{Chemical analysis}

The moisture, crude protein, crude fat, and crude ash contents of $\mathrm{BG}, \mathrm{BC}$, and $\mathrm{BP}$ were analyzed using $\mathrm{AOAC}$ (2000) methods.

\section{Color}

The color of the noodles was detected using a color dif-
Table 1. Formulation of noodle mixtures made with different mixing ratios of $\mathrm{BG}, \mathrm{BC}$, and $\mathrm{BP}$

\begin{tabular}{ccccc}
\hline \hline \multirow{2}{*}{$\begin{array}{c}\text { Types of } \\
\text { beef }\end{array}$} & \multicolumn{4}{c}{ Formulation (\%) } \\
\cline { 2 - 5 } Control & Beef addition & Flour & Water & Salt \\
BG-10\% & 10 & 70 & 29 & 1 \\
BG-15\% & 15 & 67 & 22 & 1 \\
BG-20\% & 20 & 66 & 18 & 1 \\
BG-25\% & 25 & 65 & 14 & 1 \\
\hline BC-9\% & 9 & 65 & 10 & 1 \\
BC-11\% & 11 & 63 & 25 & 1 \\
BC-13\% & 13 & 62 & 24 & 1 \\
BC-15\% & 15 & 61 & 23 & 1 \\
\hline BP-1\% & 1 & 69 & 29 & 1 \\
BP-3\% & 3 & 67 & 29 & 1 \\
BP-5\% & 5 & 65 & 29 & 1 \\
BP-7\% & 7 & 63 & 29 & 1 \\
\hline
\end{tabular}

Control, noodles with no beef added; BG, Beef ground added; BC, Beef concentrate added; BP, Beef powder added.

ference meter (Chroma meter, CR-410, Minolta Co., Japan) at a calibration of L: 97.10, a: -0.17 , and b: 2.08 on a standard white plate. Each sample was tested five times and average values of CIE L* (lightness), CIE a* (redness), and CIE $b^{*}$ (yellowness) were obtained.

\section{Texture profile analysis (TPA)}

The texture profile of the noodles before and after cooking was tested using a Texture analyzer (TA-XT2i; Stable Micro Systems Ltd., UK) with a $20-40 \mathrm{~mm}$ round probe at a pre-test speed of $0.5 \mathrm{~mm} / \mathrm{s}$, a test speed of 0.5 $\mathrm{mm} / \mathrm{s}$, a post-test speed of $0.5 \mathrm{~mm} / \mathrm{s}$, a strain of $50 \%$, and 
a $75 \%$ distance. During the experiment, the hardness, springiness, cohesiveness, gumminess, and chewiness of the noodles were analyzed using the force-distance curve acquired when the probe pressed the sample.

\section{Water absorption ratio}

The water absorption ratio of the noodles after cooking was tested by weighing them before and after cooking, and using the following equation:

([Weight after cooking-Weight before cooking]/ Weight before cooking) $\times 100$

\section{Volume}

The volumes of the noodles were calculated using the volumetric differences of water. Cooked noodles were individually placed in $300 \mathrm{~mL}$ of water in a $500-\mathrm{mL}$ mesh cylinder and the differences in scale were recorded.

\section{Turbidity}

The turbidity of cooked noodle soup with the various types of beef added was tested using a spectrophotometer (Mecasys, Optizen 2120UV, Korea) at $675 \mathrm{~nm}$ of Optical Density (OD). Cooked noodle soup was prepared under the same conditions of heating for $3 \mathrm{~min}$ each, cooled for $30 \mathrm{~min}$ at room temperature, and then made up to an equal volume of $500 \mathrm{~mL}$ with water.

\section{Sensory evaluation}

A sensory test was conducted by 15 trained panelists to evaluate cooked noodles with various types of beef added. Samples were tested by the panelists immediately after heating, to avoid changes in the sensory conditions caused by serving time differences. Appearance, color, flavor, taste, texture, and overall acceptability were evaluated using a 9-point scale ( $1=$ extremely undesirable, $9=$ extremely desirable).

\section{Statistical analysis}

An ANOVA was conducted using SAS/PC+ software. A significance test of the differences between the samples was performed using Duncan's multiple range test $(p<$
$0.05)$.

\section{Results and Discussion}

\section{Chemical Analysis}

The chemical analysis results are presented in Table 2. BG had $74.87 \%$, BC had $39.58 \%$, and BP had 5.76\% moisture content, indicating that the differences between the types of beef were large. It is possible that the variation in the moisture contents of $\mathrm{BG}, \mathrm{BC}$, and $\mathrm{BP}$ was because the mixing ratio of water and flour was changed in order to balance the moisture content in the dough and noodle. BP contained the highest proportions of crude protein and fat ( 80.10 and $6.94 \%$, respectively), and those in BG were the lowest (21.05 and 2.07\%, respectively).

\section{Color}

The colors of uncooked and cooked noodles with BG, $\mathrm{BC}$, and BP added are shown in Table 3. With a higher ratio of BG in the uncooked and cooked noodles (from 10 to $25 \%$ ), the color turned dark brown, which was obviously because of the color of the beef. The $\mathrm{L}$ and $\mathrm{b}$ values of uncooked noodles decreased, from 81.62 and 17.41 to 61.84 and 12.95 , respectively $(p<0.05)$, as the BG ratio increased. In the case of the a value, it was -1.29 in the control but rapidly increased to 6.30 after the $25 \%$ BG treatment $(p<0.05)$.

Regarding the changes in the L and $\mathrm{b}$ values in the cooked noodles, they showed a similar tendency of decreasing as the BG content increased. However, the $\mathrm{L}$ and $\mathrm{b}$ values of uncooked noodles were higher than those of cooked noodles $(p<0.05)$.

With the addition of more $\mathrm{BC}$, the $\mathrm{L}$ and a values of the uncooked and cooked noodles also decreased, even more so than those in the BG treatment, which indicated that $\mathrm{BC}$ was darker than BG. However, the a value increased from -1.08 to 2.43 in the uncooked control and from -0.74 to 3.79 in the cooked control $(p<0.05)$, which was a similar result to that obtained in the BG treatment.

In the $\mathrm{BP}$ treatment, the $\mathrm{L}$ value of the uncooked noodles decreased from 79.18 to 57.30 , but the a value increased from -0.57 in the control to 7.57 in the $7 \%$ treat-

Table 2. Chemical analysis of ground, concentrated, and powdered beef

\begin{tabular}{lccccc}
\hline \hline \multirow{2}{*}{ Types of beef } & \multicolumn{4}{c}{ Proximate composition (\%) } \\
\cline { 3 - 6 } & \multirow{3}{*}{ Contents } & Moisture & Crude protein & Crude fat & Crude Ash \\
& Ground beef & $74.87 \pm 0.20$ & $21.05 \pm 2.07$ & $2.07 \pm 0.52$ & $1.14 \pm 0.01$ \\
& Concentrated beef & $39.58 \pm 0.24$ & $52.36 \pm 1.36$ & $4.03 \pm 0.83$ & $3.02 \pm 0.03$ \\
& Powdered beef & $5.76 \pm 0.04$ & $80.10 \pm 1.99$ & $6.94 \pm 0.30$ & $4.52 \pm 0.03$ \\
\hline
\end{tabular}


Table 3. Color of uncooked and cooked noodles made with different mixing ratios of BG, BC, and BP

\begin{tabular}{|c|c|c|c|c|}
\hline \multirow{2}{*}{\multicolumn{2}{|c|}{ Treatment }} & \multicolumn{3}{|c|}{ Hunter's color value } \\
\hline & & $\mathrm{L}$ & $a$ & $\mathrm{~b}$ \\
\hline \multirow{5}{*}{ Uncooked cooked } & Control & $81.62 \pm 0.06^{\mathrm{a}}$ & $-1.29 \pm 0.01^{\mathrm{e}}$ & $17.41 \pm 0.04^{\mathrm{a}}$ \\
\hline & BG-10\% & $71.42 \pm 0.19^{\mathrm{b}}$ & $3.37 \pm 0.02^{\mathrm{d}}$ & $14.52 \pm 0.16^{\mathrm{b}}$ \\
\hline & BG-15\% & $67.12 \pm 0.22^{\mathrm{c}}$ & $4.77 \pm 0.01^{\mathrm{c}}$ & $13.92 \pm 0.04^{\mathrm{c}}$ \\
\hline & BG-20\% & $64.14 \pm 0.22^{\mathrm{d}}$ & $5.46 \pm 0.02^{\mathrm{b}}$ & $13.28 \pm 0.04^{\mathrm{d}}$ \\
\hline & BG- $25 \%$ & $61.84 \pm 0.21^{\mathrm{e}}$ & $6.3 \pm 0.01^{\mathrm{a}}$ & $12.95 \pm 0.07^{\mathrm{e}}$ \\
\hline \multirow{5}{*}{ Cooked noodle } & Control & $72.36 \pm 0.38^{\mathrm{a}}$ & $-0.88 \pm 0.01^{\mathrm{e}}$ & $16.10 \pm 0.06^{\mathrm{a}}$ \\
\hline & BG- $10 \%$ & $59.21 \pm 0.25^{\mathrm{b}}$ & $4.78 \pm 0.02^{\mathrm{d}}$ & $12.24 \pm 0.07^{b}$ \\
\hline & BG- $15 \%$ & $53.44 \pm 0.78^{\mathrm{c}}$ & $5.71 \pm 0.01^{\mathrm{c}}$ & $10.19 \pm 0.20^{\mathrm{c}}$ \\
\hline & BG- $20 \%$ & $50.43 \pm 0.31^{\mathrm{d}}$ & $6.13 \pm 0.04^{b}$ & $9.53 \pm 0.20^{\mathrm{d}}$ \\
\hline & BG- $25 \%$ & $46.93 \pm 0.30^{\mathrm{e}}$ & $6.56 \pm 0.04^{\mathrm{a}}$ & $8.08 \pm 0.10^{\mathrm{e}}$ \\
\hline \multirow{5}{*}{ Uncooked noodle } & Control & $82.23 \pm 0.17^{\mathrm{a}}$ & $-1.18 \pm 0.02^{\mathrm{e}}$ & $17.47 \pm 0.05^{\mathrm{a}}$ \\
\hline & BC- $-9 \%$ & $75.97 \pm 0.09^{b}$ & $1.35 \pm 0.01^{\mathrm{d}}$ & $15.34 \pm 0.07^{b}$ \\
\hline & BC- $-11 \%$ & $75.95 \pm 0.08^{b}$ & $1.44 \pm 0.02^{\mathrm{c}}$ & $15.10 \pm 0.15^{\mathrm{c}}$ \\
\hline & BC- $-13 \%$ & $73.28 \pm 0.34^{\mathrm{c}}$ & $2.06 \pm 0.05^{\mathrm{b}}$ & $14.79 \pm 0.03^{\mathrm{d}}$ \\
\hline & BC $-15 \%$ & $72.50 \pm 0.25^{\mathrm{d}}$ & $2.43 \pm 0.02^{\mathrm{a}}$ & $14.68 \pm 0.11^{\mathrm{e}}$ \\
\hline \multirow{5}{*}{ Cooked noodle } & Control & $73.35 \pm 0.26^{\mathrm{a}}$ & $-0.74 \pm 0.01^{\mathrm{e}}$ & $15.44 \pm 0.12^{\mathrm{a}}$ \\
\hline & BC- $-9 \%$ & $62.38 \pm 1.22^{\mathrm{b}}$ & $2.41 \pm 0.01^{\mathrm{d}}$ & $14.19 \pm 0.25^{\mathrm{b}}$ \\
\hline & BC- $-11 \%$ & $63.13 \pm 1.36^{\mathrm{b}}$ & $2.82 \pm 0.02^{\mathrm{c}}$ & $13.98 \pm 0.45^{\mathrm{b}}$ \\
\hline & BC- $13 \%$ & $61.99 \pm 0.29^{b}$ & $3.33 \pm 0.03^{b}$ & $13.23 \pm 0.4^{\mathrm{c}}$ \\
\hline & BC- $-15 \%$ & $59.02 \pm 0.55^{\mathrm{c}}$ & $3.79 \pm 0.03^{\mathrm{a}}$ & $13.02 \pm 0.23^{\mathrm{c}}$ \\
\hline \multirow{5}{*}{ Uncooked noodle } & Control & $79.18 \pm 0.16^{\mathrm{a}}$ & $-0.57 \pm 0.01^{\mathrm{e}}$ & $16.68 \pm 0.03^{\mathrm{d}}$ \\
\hline & BP-1\% & $72.09 \pm 0.22^{\mathrm{b}}$ & $3.23 \pm 0.08^{\mathrm{d}}$ & $18.33 \pm 0.06^{\mathrm{c}}$ \\
\hline & BP-3\% & $64.14 \pm 0.14^{\mathrm{c}}$ & $5.94 \pm 0.02^{\mathrm{c}}$ & $19.82 \pm 0.07^{\mathrm{a}}$ \\
\hline & BP-5\% & $60.55 \pm 0.38^{\mathrm{d}}$ & $6.85 \pm 0.04^{\mathrm{b}}$ & $19.27 \pm 0.15^{\mathrm{b}}$ \\
\hline & BP-7\% & $57.30 \pm 0.28^{\mathrm{e}}$ & $7.57 \pm 0.02^{\mathrm{a}}$ & $19.15 \pm 0.17^{b}$ \\
\hline \multirow{5}{*}{ Cooked noodle } & Control & $71.81 \pm 0.56^{\mathrm{a}}$ & $-0.43 \pm 0.02^{\mathrm{e}}$ & $15.31 \pm 0.28^{\mathrm{a}}$ \\
\hline & BP-1\% & $60.47 \pm 0.36^{\mathrm{b}}$ & $3.80 \pm 0.02^{\mathrm{d}}$ & $15.50 \pm 0.18^{\mathrm{a}}$ \\
\hline & BP-3\% & $50.37 \pm 0.44^{\mathrm{c}}$ & $6.63 \pm 0.01^{\mathrm{c}}$ & $14.16 \pm 0.23^{b}$ \\
\hline & ВР-5\% & $46.79 \pm 0.35^{\mathrm{d}}$ & $7.75 \pm 0.05^{b}$ & $13.22 \pm 0.19^{\mathrm{c}}$ \\
\hline & ВР-7\% & $40.68 \pm 0.7^{\mathrm{e}}$ & $8.37 \pm 0.04^{\mathrm{a}}$ & $10.69 \pm 0.32^{\mathrm{d}}$ \\
\hline
\end{tabular}

Control, noodles with no beef added; BG, Beef ground added; BC, Beef concentrate added; BP, Beef powder added.

Values are Means $\pm \mathrm{SD}(\mathrm{n}=3)$.

Means with the same letter in a column are not significantly different $(p>0.05)$.

ment group $(p<0.05)$.

The $\mathrm{L}$ value of cooked noodles also decreased with increasing $\mathrm{BP}$ content, and the a value increased with the $\mathrm{BP}$ content, from -0.43 in the control to 8.37 in the $7 \%$ treatment $(p<0.05)$.

Similar results have been obtained in previous studies that have investigated color changes in noodles with various additives such as shiitake mushrooms (Lentinula edodes) (Kim et al., 2008), Sanghwang mushrooms (Phellinus linteus) (Kim et al., 2005), king oyster mushrooms (Pleurotus eryngii) (Sung et al., 2008), or kudzu powder (Lee et al., 2000). By increasing the contents of additives such as chlorella extracts (Park and Cho, 2004), lotus leaf powder (Park et al., 2010), Ligularia Fischeri and Angelica Gigas Nakai extracts (Chang et al., 2008), bamboo leaf powder (Oh, 2004), or mulberry leaf powder (Kim, 2002) in the noodle, $\mathrm{L}$ and a values decreased and $\mathrm{b}$ values increased. Recently, there have been reports that consumers prefer colored noodles to white ones, because they believe that colored additives might help to improve their health (Cho, 2010; Cho and Kim, 2009; Park et al., 2010).

\section{Texture profile}

The results of the TPA of uncooked and cooked noodles made with various mixing ratios of $\mathrm{BG}, \mathrm{BC}$, and $\mathrm{BP}$ are presented in Table 4.

In the case of the uncooked noodle, the more BG that was added, the harder was the noodle, but the $\mathrm{BC}$ and $\mathrm{BP}$ treatments had the opposite effect, and the more the $\mathrm{BC}$ or BP that was added, the softer was the noodle. We believe that the $\mathrm{BG}$ particles that were not emulsified in the noodle affected the hardness result. In the case of the 
Table 4. Texture profiles of uncooked and cooked noodles made with different mixing ratios of BG, BC, and BP

\begin{tabular}{|c|c|c|c|c|c|c|}
\hline$\overline{\text { Tre }}$ & & Hardness(g) & Springiness & Cohesiveness & "Gumminess & Chewiness \\
\hline \multirow{5}{*}{$\begin{array}{l}\text { Uncooked } \\
\text { noodle }\end{array}$} & Control & $2,844.3 \pm 104.1^{\mathrm{c}}$ & $0.80 \pm 0.07^{\mathrm{a}}$ & $0.50 \pm 0.03^{\mathrm{a}}$ & $1,454.6 \pm 153.9^{b}$ & $1,226.6 \pm 61.7^{\mathrm{a}}$ \\
\hline & BG-10\% & $2,875 \cdot 2 \pm 71.3^{\mathrm{c}}$ & $0.72 \pm 0.19^{\mathrm{a}}$ & $0.52 \pm 0.01^{\mathrm{a}}$ & $1,532.9 \pm 91.6^{\mathrm{b}}$ & $1,165.9 \pm 64.9^{\mathrm{ab}}$ \\
\hline & BG- $15 \%$ & $3,381.7 \pm 54.8^{\mathrm{b}}$ & $0.74 \pm 0.18^{\mathrm{a}}$ & $0.54 \pm 0.01^{\mathrm{a}}$ & $1,527.2 \pm 120.8^{b}$ & $1,134.7 \pm 43.6^{\mathrm{b}}$ \\
\hline & BG-20\% & $3,327.7 \pm 63.4^{\mathrm{b}}$ & $0.76 \pm 0.08^{\mathrm{a}}$ & $0.51 \pm 0.03^{\mathrm{a}}$ & $1,804.6 \pm 57.1^{\mathrm{a}}$ & $1,129.0 \pm 34.0^{\mathrm{b}}$ \\
\hline & BG- $25 \%$ & $3,534.7 \pm 75.8^{\mathrm{a}}$ & $0.86 \pm 0.12^{\mathrm{a}}$ & $0.54 \pm 0.02^{\mathrm{a}}$ & $1,897.0 \pm 116.0^{\mathrm{a}}$ & $1,114.8 \pm 78.7^{\mathrm{b}}$ \\
\hline \multirow{5}{*}{$\begin{array}{l}\text { Cooked } \\
\text { noodle }\end{array}$} & Control & $1,513.5 \pm 71.2^{\mathrm{c}}$ & $1.49 \pm 0.61^{\mathrm{a}}$ & $0.70 \pm 0.02^{\mathrm{a}}$ & $1,049.8 \pm 87.9^{\mathrm{c}}$ & $1,182.2 \pm 53.6^{b}$ \\
\hline & BG-10\% & $1,762.0 \pm 67.2^{\mathrm{b}}$ & $1.27 \pm 0.12^{\mathrm{ab}}$ & $0.71 \pm 0.02^{\mathrm{a}}$ & $1,258.9 \pm 37.1^{\mathrm{b}}$ & $1,166.4 \pm 55.6^{\mathrm{b}}$ \\
\hline & BG-15\% & $1,851.0 \pm 105.5^{\mathrm{b}}$ & $1.21 \pm 0.49^{\mathrm{ab}}$ & $0.71 \pm 0.01^{\mathrm{a}}$ & $1,309.7 \pm 62.2^{\mathrm{ab}}$ & $1,181.2 \pm 99.1^{\mathrm{b}}$ \\
\hline & BG-20\% & $1,965.8 \pm 84.1^{\mathrm{a}}$ & $0.91 \pm 0.08^{\mathrm{b}}$ & $0.69 \pm 0.03^{\mathrm{a}}$ & $1,344.0 \pm 133.5^{\mathrm{ab}}$ & $1,249.5 \pm 48.7^{\mathrm{ab}}$ \\
\hline & BG-25\% & $2,017.7 \pm 49.2^{\mathrm{a}}$ & $0.89 \pm 0.07^{\mathrm{b}}$ & $0.71 \pm 0.03^{\mathrm{a}}$ & $1,415.9 \pm 46.0^{\mathrm{a}}$ & $1,329.5 \pm 69.7^{\mathrm{a}}$ \\
\hline \multirow{5}{*}{$\begin{array}{l}\text { Uncooked } \\
\text { noodle }\end{array}$} & Control & $3,548.9 \pm 368.1^{\mathrm{a}}$ & $0.72 \pm 0.07^{b}$ & $0.53 \pm 0.04^{\mathrm{a}}$ & $1,898.5 \pm 325.4^{\mathrm{a}}$ & $1,295.9 \pm 62.8^{\mathrm{a}}$ \\
\hline & BC- $-9 \%$ & $2,168.6 \pm 116.6^{\mathrm{b}}$ & $0.97 \pm 0.00^{\mathrm{a}}$ & $0.51 \pm 0.02^{\mathrm{ab}}$ & $1,098.8 \pm 76.8^{\mathrm{b}}$ & $1,073.3 \pm 52.5^{\mathrm{b}}$ \\
\hline & BC- $-11 \%$ & $2,114.3 \pm 149.6^{\mathrm{b}}$ & $0.97 \pm 0.01^{\mathrm{a}}$ & $0.50 \pm 0.03^{\mathrm{ab}}$ & $1,091.8 \pm 142.2^{b}$ & $989.0 \pm 64.7^{\mathrm{b}}$ \\
\hline & BC- $-13 \%$ & $2,076.4 \pm 139.1^{\mathrm{b}}$ & $0.97 \pm 0.00^{\mathrm{a}}$ & $0.51 \pm 0.02^{\mathrm{ab}}$ & $1,057.9 \pm 77.0^{\mathrm{b}}$ & $1,022.4 \pm 75.5^{\mathrm{b}}$ \\
\hline & BC- $-15 \%$ & $1,887.7 \pm 113.9^{b}$ & $0.97 \pm 0.04^{\mathrm{a}}$ & $0.47 \pm 0.02^{\mathrm{b}}$ & $893.4 \pm 70.6^{\mathrm{b}}$ & $820.9 \pm 89.0^{c}$ \\
\hline \multirow{5}{*}{$\begin{array}{l}\text { Cooked } \\
\text { noodle }\end{array}$} & Control & $1,959.5 \pm 111.3^{\mathrm{a}}$ & $0.92 \pm 0.01^{\mathrm{a}}$ & $0.76 \pm 0.02^{\mathrm{a}}$ & $1,494.7 \pm 85.8^{\mathrm{a}}$ & $1,377.5 \pm 73.1^{\mathrm{a}}$ \\
\hline & BC- $-9 \%$ & $1,518.6 \pm 91.0^{\mathrm{b}}$ & $0.93 \pm 0.01^{\mathrm{a}}$ & $0.72 \pm 0.03^{\mathrm{b}}$ & $1,172.3 \pm 59.1^{\mathrm{b}}$ & $1,089.1 \pm 58.9^{b}$ \\
\hline & BC- $-11 \%$ & $1,495.4 \pm 131.2^{b}$ & $0.93 \pm 0.00^{\mathrm{a}}$ & $0.71 \pm 0.02^{\mathrm{b}}$ & $1,115.3 \pm 39.7^{\mathrm{bc}}$ & $1,018.3 \pm 92.1^{b c}$ \\
\hline & BC- $-13 \%$ & $1,4730.3 \pm 70.3^{b}$ & $0.93 \pm 0.01^{\mathrm{a}}$ & $0.71 \pm 0.02^{\mathrm{b}}$ & $1,087.0 \pm 57.4^{\mathrm{c}}$ & $958.8 \pm 76.6^{\mathrm{c}}$ \\
\hline & BC- $-15 \%$ & $1,397.9 \pm 108.3^{\mathrm{b}}$ & $0.92 \pm 0.02^{\mathrm{a}}$ & $0.69 \pm 0.02^{\mathrm{b}}$ & $963.2 \pm 43.2^{\mathrm{d}}$ & $854.1 \pm 69.3^{\mathrm{d}}$ \\
\hline \multirow{5}{*}{$\begin{array}{l}\text { Uncooked } \\
\text { noodle }\end{array}$} & Control & $2,897 \cdot 6 \pm 75.6^{\mathrm{a}}$ & $0.54 \pm 0.04^{b}$ & $0.47 \pm 0.02^{\mathrm{b}}$ & $1,349.3 \pm 21.2^{\mathrm{a}}$ & $700.9 \pm 25.5^{\mathrm{a}}$ \\
\hline & BP-1\% & $2,525.2 \pm 97.3^{\mathrm{b}}$ & $0.71 \pm 0.23^{\mathrm{ab}}$ & $0.49 \pm 0.04^{\mathrm{ab}}$ & $1,230.2 \pm 53.7^{\mathrm{b}}$ & $677.3 \pm 79.4^{\mathrm{ab}}$ \\
\hline & ВР-3\% & $1,769.9 \pm 0.1^{\mathrm{c}}$ & $0.83 \pm 0.16^{\mathrm{a}}$ & $0.49 \pm 0.03^{\mathrm{ab}}$ & $848.1 \pm 31.0^{c}$ & $618.5 \pm 45.1^{\mathrm{bc}}$ \\
\hline & ВР-5\% & $1,514.7 \pm 44.3^{\mathrm{d}}$ & $0.87 \pm 0.13^{\mathrm{a}}$ & $0.50 \pm 0.05^{\mathrm{ab}}$ & $727.1 \pm 68.3^{\mathrm{d}}$ & $563.3 \pm 53.6^{\mathrm{cd}}$ \\
\hline & BP-7\% & $1,190.7 \pm 46.2^{\mathrm{e}}$ & $0.89 \pm 0.11^{\mathrm{a}}$ & $0.53 \pm 0.06^{\mathrm{a}}$ & $605.7 \pm 42.0^{\mathrm{e}}$ & $532.4 \pm 11.2^{\mathrm{d}}$ \\
\hline \multirow{5}{*}{$\begin{array}{c}\text { Cooked } \\
\text { noodle }\end{array}$} & Control & $1,648.1 \pm 25.6^{\mathrm{a}}$ & $0.91 \pm 0.07^{\mathrm{a}}$ & $0.71 \pm 0.01^{\mathrm{a}}$ & $1,204.7 \pm 29.0^{\mathrm{a}}$ & $1,126.7 \pm 62.3^{\mathrm{a}}$ \\
\hline & BP-1\% & $1,508.9 \pm 54.1^{\mathrm{b}}$ & $0.93 \pm 0.06^{\mathrm{a}}$ & $0.70 \pm 0.01^{\mathrm{a}}$ & $1,058.2 \pm 76.9^{\mathrm{b}}$ & $976.5 \pm 51.3^{\mathrm{b}}$ \\
\hline & BP-3\% & $1,465.7 \pm 94.0^{\mathrm{b}}$ & $0.94 \pm 0.06^{\mathrm{a}}$ & $0.64 \pm 0.02^{\mathrm{b}}$ & $897.1 \pm 67.5^{\mathrm{c}}$ & $908.9 \pm 26.0^{\mathrm{b}}$ \\
\hline & BP-5\% & $1,036.5 \pm 83.9^{\mathrm{c}}$ & $0.94 \pm 0.07^{\mathrm{a}}$ & $0.63 \pm 0.03^{\mathrm{b}}$ & $657.9 \pm 41.0^{\mathrm{d}}$ & $593.4 \pm 68.0^{\mathrm{c}}$ \\
\hline & ВР-7\% & $1,015.8 \pm 35.8^{\mathrm{c}}$ & $0.93 \pm 0.06^{\mathrm{a}}$ & $0.65 \pm 0.03^{\mathrm{b}}$ & $721.5 \pm 43.4^{\mathrm{d}}$ & $580.3 \pm 82.3^{\mathrm{c}}$ \\
\hline
\end{tabular}

Control, noodles with no beef added; BG, Beef ground added; BC, Beef concentrate added; BP, Beef powder added.

Values are Means $\pm \mathrm{SD}(\mathrm{n}=3)$.

Means with same letter in a column are not significantly different $(p>0.05)$.

cooked noodle, BG, BC, and $\mathrm{BP}$ resulted in the same pattern of hardness as previously observed in the uncooked noodle, which increased with increasing amounts of BG, but decreased with increasing BC or BP. Uncooked noodles were harder than cooked noodles because cooked noodles contain water, which affects their texture.

In the springiness and chewiness tests of the BG treatments in the cooked noodle, there were no significant differences except for between the $20 \%$ addition treatment and the control. This result suggests that the BG $10 \%$ and BG $15 \%$ treatments were within a reasonable range in order to maintain their texture capacity in a BG treatment $(p<0.05)$.

In the TPA of the BC treatment, although there were significant differences between the control and each treatment, except for the cohesiveness of the uncooked noodle, there were no differences between treatments except for the $15 \%$ addition of $\mathrm{BC}$, regarding its chewiness. In the TPA test of cooked noodles, there was no significant difference between the $\mathrm{BC}$ treatments but all of them had lower values than those of the control, except for springiness $(p>0.05)$. Therefore, adding $9 \%$ and $11 \%$ of $\mathrm{BC}$ to uncooked and cooked noodles, respectively, were the best conditions in the $\mathrm{BC}$ treatments.

In the TPA test of the BP treatments with uncooked noodles, hardness, gumminess, and chewiness decreased as BP increased, and springiness and cohesiveness also increased. In the cooked noodle, the results were similar to those of the uncooked noodle, that is the hardness, gumminess, and chewiness decreased, but springiness did not change ( $p>0.05$ ). Therefore, adding 3\% and 5\% BP to uncooked and cooked noodles, respectively, is good for noodle texture.

These results are similar to results obtained in previous 
Table 5. Water absorption ratio, volume, and soup turbidity of cooked noodles made with different mixing ratios of BG, BC, and BP

\begin{tabular}{cccc}
\hline \hline Treatment & $\begin{array}{c}\text { Water absorption } \\
(\%)\end{array}$ & $\begin{array}{c}\text { Volume } \\
(\mathrm{mL})\end{array}$ & $\begin{array}{c}\text { Turbidity of } \\
\text { Soup (O.D. })\end{array}$ \\
\hline Control & $56.93 \pm 0.1^{\mathrm{a}}$ & $75 \pm 0.2^{\mathrm{a}}$ & $0.26 \pm 0.00^{\mathrm{b}}$ \\
BG-10\% & $45.32 \pm 0.2^{\mathrm{b}}$ & $65 \pm 0.1^{\mathrm{b}}$ & $0.24 \pm 0.01^{\mathrm{c}}$ \\
BG-15\% & $45.40 \pm 0.2^{\mathrm{b}}$ & $65 \pm 0.1^{\mathrm{b}}$ & $0.25 \pm 0.00^{\mathrm{c}}$ \\
BG-20\% & $45.01 \pm 0.1^{\mathrm{b}}$ & $65 \pm 0.2^{\mathrm{b}}$ & $0.27 \pm 0.00^{\mathrm{ab}}$ \\
BG-25\% & $44.25 \pm 0.3^{\mathrm{c}}$ & $65 \pm 0.1^{\mathrm{b}}$ & $0.28 \pm 0.01^{\mathrm{a}}$ \\
\hline Control & $75.52 \pm 0.4^{\mathrm{a}}$ & $80 \pm 0.2^{\mathrm{a}}$ & $0.21 \pm 0.00^{\mathrm{d}}$ \\
BC-9\% & $74.26 \pm 0.3^{\mathrm{b}}$ & $80 \pm 0.1^{\mathrm{a}}$ & $0.24 \pm 0.00^{\mathrm{c}}$ \\
BC-11\% & $70.79 \pm 0.2^{\mathrm{c}}$ & $75 \pm 0.1^{\mathrm{b}}$ & $0.25 \pm 0.00^{\mathrm{b}}$ \\
BC-13\% & $70.72 \pm 0.3^{\mathrm{c}}$ & $75 \pm 0.2^{\mathrm{b}}$ & $0.29 \pm 0.00^{\mathrm{a}}$ \\
BC-15\% & $62.66 \pm 0.3^{\mathrm{d}}$ & $70 \pm 0.1^{\mathrm{c}}$ & $0.29 \pm 0.00^{\mathrm{a}}$ \\
\hline Control & $83.38 \pm 0.4^{\mathrm{a}}$ & $90 \pm 0.1^{\mathrm{a}}$ & $0.25 \pm 0.01^{\mathrm{e}}$ \\
BP-1\% & $67.96 \pm 0.3^{\mathrm{b}}$ & $70 \pm 0.2^{\mathrm{b}}$ & $0.27 \pm 0.01^{\mathrm{d}}$ \\
BP-3\% & $59.81 \pm 0.2^{\mathrm{c}}$ & $72 \pm 0.1^{\mathrm{b}}$ & $0.29 \pm 0.01^{\mathrm{c}}$ \\
BP-5\% & $59.57 \pm 0.3^{\mathrm{c}}$ & $69 \pm 0.2^{\mathrm{b}}$ & $0.31 \pm 0.00^{\mathrm{b}}$ \\
BP-7\% & $48.46 \pm 0.2^{\mathrm{d}}$ & $65 \pm 0.2^{\mathrm{c}}$ & $0.37 \pm 0.00^{\mathrm{a}}$ \\
\hline Contol $\mathrm{n}$ & &
\end{tabular}

Control, noodles with no beef added; BG, Beef ground added; $\mathrm{BC}$, Beef concentrate added; BP, Beef powder added.

Values are Means $\pm \mathrm{SD}(\mathrm{n}=3)$.

Means with the same letter in a column are not significantly different $(p>0.05)$.

studies that have investigated the effects of additives, such as Dioscorea japonica flour (Park and Cho, 2006), cactus powder (Chong and Park, 2003), onion powder (Kim and Shim, 2006), and lotus leaf powder (Park et al., 2010) on noodle texture, and have found that noodle hardness increases if the volume of additives is too high.

\section{Cooking properties}

The results regarding cooking properties, such as the water absorption ratio, volume, and soup turbidity of noodles made with various mixing ratios of $\mathrm{BG}, \mathrm{BC}$, and $\mathrm{BP}$ are presented in Table 5 .

The water absorption ratios of the $\mathrm{BG}, \mathrm{BC}$, and $\mathrm{BP}$ cooked noodles significantly decreased compared to the control, while the mixing ratio increased, regardless of the type of meat. In each test of $25 \%$ of BG, $15 \%$ of BC, and $7 \%$ of BP, these treatments exhibited the lowest value. This may have been caused by the moisture content of each additive affecting water absorption in the noodle, and that BP had a lower capacity for water absorption than did the other additives $(p<0.05)$.

There were no significant differences with the control in the volumes of cooked noodles with BG added, but there was a significant difference between the BG $10 \%$ and BG $25 \%$ treatments $(p<0.05)$. In the $\mathrm{BC}$ treatment, the control and the $\mathrm{BC} 9 \%$ treatment were also signifi- cantly different $(p<0.05)$, but were lower than in the $\mathrm{BC}$ $11 \%$ treatment. In the BP treatment, the control exhibited the highest value $(90 \mathrm{~mL})$, but decreased gradually to $65 \%$ in BP $7 \%$. These results are similar to those obtained by a study that reported that there is a positive relationship between weight and volume in the cooked noodle (Kim et al., 1996).

The turbidity test of cooked noodle soup was conducted, according to the various mixing ratios of $\mathrm{BG}, \mathrm{BC}$, and $\mathrm{BP}$, to ascertain the effect of transferring solid content from noodle to soup. With a higher content of $\mathrm{BG}, \mathrm{BC}$, or $\mathrm{BP}$, the higher the turbidity value was. For each treatment, the turbidity values were from $0.24 \mathrm{OD}$ to $0.28 \mathrm{OD}$ in $\mathrm{BG}$, from $0.24 \mathrm{OD}$ to $0.29 \mathrm{OD}$ in $\mathrm{BC}$, and from 0.27 OD to 0.37 OD in $\mathrm{BP}(p<0.05)$. These results are similar to those obtained by studies that have reported that the more additives there are in a noodle, the more solid content is lost while cooking, and the greater the turbidity (Hwang and Jang, 2001; Kim, 1998; Lee et al., 1999; Lee and Kim, 2000). All of these results were caused by the weakness of the noodle biding capacity, because additives, such as meat that replaces flour, do not have sufficient strength when heated.

\section{Sensory evaluation}

The results of the sensory evaluation of the noodles are presented in Table 6 . The evaluation result of the sensory test decreased by increasing BG from $10 \%$ to $25 \%$. In this experiment, the $10 \% \mathrm{BG}$ treatment obtained the best results among the BG treatments, and for some results, such as appearance, color, test, and overall acceptability, even exhibited higher scores than those of the control, even when there were no significant differences $(p>0.05)$. In the sensory test of noodles that added various ratios of BC from $9 \%$ to $15 \%$, all the treatments had higher scores than those of the control, except for appearance and color in the $\mathrm{BC} 13 \%$ and $15 \%$ treatments.

In the texture test, $\mathrm{BC} 13 \%$ had the highest score with 7.3 , and $\mathrm{BC} 9 \%$ had the second highest score of 6.8 . BC $11 \%$ had the best score (6.8) for overall acceptability, but there was no significant difference $(p>0.05)$. The above results suggest that the $\mathrm{BC}$-added noodle has the potential to be a qualified noodle, which includes meat.

In the sensory test of noodles with BP $1 \%$ to $7 \%$, all of the treatments yielded higher scores for every test item than those of the control, except for appearance and color in the BP 7\% treatment. It is believed that the panel recognized the taste of beef in the noodles and evaluated them to be better than the normal-flavored noodles of the 
Table 6. Sensory evaluation of cooked noodles made with different mixing ratios of BG, BC, and BP

\begin{tabular}{ccccccc}
\hline \hline Treatment & Appearance & Color & Flavor & Taste & Texture & Overall acceptability \\
\hline Control & $6.7 \pm 0.7^{\mathrm{ab}}$ & $6.8 \pm 0.7^{\mathrm{a}}$ & $6.8 \pm 0.8^{\mathrm{a}}$ & $7.1 \pm 0.9^{\mathrm{a}}$ & $7.2 \pm 0.7^{\mathrm{a}}$ & $7.0 \pm 1.0^{\mathrm{a}}$ \\
BG-10\% & $7.0 \pm 0.5^{\mathrm{a}}$ & $7.2 \pm 0.7^{\mathrm{a}}$ & $6.6 \pm 0.5^{\mathrm{a}}$ & $7.3 \pm 0.7^{\mathrm{a}}$ & $7.2 \pm 1.1^{\mathrm{a}}$ & $7.2 \pm 0.8^{\mathrm{a}}$ \\
BG-15\% & $6.4 \pm 0.9^{\mathrm{ab}}$ & $6.9 \pm 1.1^{\mathrm{a}}$ & $6.4 \pm 0.7^{\mathrm{a}}$ & $7.2 \pm 0.7^{\mathrm{a}}$ & $6.9 \pm 0.9^{\mathrm{a}}$ & $7.0 \pm 1.0^{\mathrm{a}}$ \\
BG-20\% & $6.4 \pm 1.1^{\mathrm{ab}}$ & $6.4 \pm 0.9^{\mathrm{ab}}$ & $6.1 \pm 0.8^{\mathrm{ab}}$ & $6.3 \pm 0.7^{\mathrm{b}}$ & $6.7 \pm 1.0^{\mathrm{a}}$ & $6.3 \pm 0.7^{\mathrm{a}}$ \\
BG-25\% & $6.0 \pm 1.2^{\mathrm{b}}$ & $5.8 \pm 1.1^{\mathrm{b}}$ & $5.3 \pm 1.2^{\mathrm{b}}$ & $5.7 \pm 1.0^{\mathrm{b}}$ & $6.3 \pm 1.2^{\mathrm{a}}$ & $5.4 \pm 1.0^{\mathrm{b}}$ \\
\hline Control & $6.4 \pm 0.7^{\mathrm{a}}$ & $6.3 \pm 0.7^{\mathrm{ab}}$ & $5.9 \pm 0.8^{\mathrm{a}}$ & $6.0 \pm 0.7^{\mathrm{a}}$ & $6.6 \pm 1.1^{\mathrm{a}}$ & $6.2 \pm 0.7^{\mathrm{a}}$ \\
BC-9\% & $6.7 \pm 1.0^{\mathrm{a}}$ & $6.6 \pm 1.0^{\mathrm{a}}$ & $6.4 \pm 1.0^{\mathrm{a}}$ & $6.2 \pm 1.3^{\mathrm{a}}$ & $6.8 \pm 1.3^{\mathrm{a}}$ & $6.7 \pm 0.9^{\mathrm{a}}$ \\
BC-11\% & $6.8 \pm 1.1^{\mathrm{a}}$ & $6.3 \pm 1.3^{\mathrm{ab}}$ & $6.4 \pm 1.1^{\mathrm{a}}$ & $6.8 \pm 1.1^{\mathrm{a}}$ & $6.6 \pm 1.4^{\mathrm{a}}$ & $6.8 \pm 1.1^{\mathrm{a}}$ \\
BC-13\% & $5.9 \pm 1.4^{\mathrm{ab}}$ & $5.9 \pm 1.4^{\mathrm{ab}}$ & $6.8 \pm 1.0^{\mathrm{a}}$ & $6.8 \pm 1.4^{\mathrm{a}}$ & $7.3 \pm 0.7^{\mathrm{a}}$ & $6.7 \pm 0.9^{\mathrm{a}}$ \\
BC-15\% & $5.1 \pm 1.5^{\mathrm{b}}$ & $5.1 \pm 1.5^{\mathrm{b}}$ & $6.3 \pm 1.5^{\mathrm{a}}$ & $6.4 \pm 1.3^{\mathrm{a}}$ & $6.7 \pm 1.0^{\mathrm{a}}$ & $6.2 \pm 1.4^{\mathrm{a}}$ \\
\hline Control & $6.3 \pm 1.0^{\mathrm{ab}}$ & $6.3 \pm 1.2^{\mathrm{ab}}$ & $5.8 \pm 1.0^{\mathrm{b}}$ & $5.6 \pm 1.1^{\mathrm{b}}$ & $6.1 \pm 1.6^{\mathrm{a}}$ & $5.9 \pm 1.2^{\mathrm{b}}$ \\
BP-1\% & $7.3 \pm 0.9^{\mathrm{a}}$ & $7.3 \pm 0.9^{\mathrm{a}}$ & $6.4 \pm 0.9^{\mathrm{ab}}$ & $6.3 \pm 1.0^{\mathrm{ab}}$ & $6.3 \pm 1.3^{\mathrm{a}}$ & $6.5 \pm 0.9^{\mathrm{ab}}$ \\
BP-3\% & $6.9 \pm 1.5^{\mathrm{a}}$ & $7.1 \pm 1.1^{\mathrm{a}}$ & $6.8 \pm 0.7^{\mathrm{ab}}$ & $6.9 \pm 1.4^{\mathrm{a}}$ & $7.3 \pm 0.5^{\mathrm{a}}$ & $7.4 \pm 0.7^{\mathrm{a}}$ \\
BP-5\% & $6.4 \pm 0.9^{\mathrm{ab}}$ & $6.4 \pm 1.3^{\mathrm{ab}}$ & $7.1 \pm 0.8^{\mathrm{a}}$ & $7.1 \pm 0.8^{\mathrm{a}}$ & $7.1 \pm 0.6^{\mathrm{a}}$ & $7.3 \pm 0.9^{\mathrm{a}}$ \\
BP-7\% & $5.3 \pm 1.3^{\mathrm{b}}$ & $5.3 \pm 1.5^{\mathrm{b}}$ & $6.6 \pm 1.1^{\mathrm{ab}}$ & $6.9 \pm 0.8^{\mathrm{a}}$ & $6.8 \pm 1.0^{\mathrm{a}}$ & $6.8 \pm 1.0^{\mathrm{ab}}$ \\
\hline
\end{tabular}

Control, noodles with no beef added; BG, Beef ground added; BC, Beef concentrate added; BP, Beef powder added.

Hedonic scale: 1 (extremely bad) to 9 (extremely good).

Values are Means $\pm \mathrm{SD}(\mathrm{n}=3)$.

${ }^{\mathrm{a}-\mathrm{b}}$ Means with the same letter in a column are not significantly different $(p>0.05)$.

control. The taste and overall acceptability of BP $3 \%$ was significantly different to that in the control $(p<0.05)$. In addition, the scores for the other tests, such as appearance, color, flavor, and texture, were higher for BP 3\% than for the control, even when there was no significant difference. Therefore, BG 10\%, BC 11\%, and BP 3\% had the best results in the sensory evaluation test.

\section{References}

1. AOAC (2000) Official method of analysis. 19th ed, Association of Official Analytical Chemists, Washington DC, USA.

2. Chang, S. K., Kim, J. H., and Oh, H. S. (2008) The development of functional cold buckwheat noodles using biological activity of hot water extracts of Ligularia fischeri and Angelica gigas nakai. Korean J. Food Culture 23, 479-488.

3. Cho, H. S. (2010) Rheological properties of dried noodles with added Enteromorpha intestinalis powder. J. Asian Soc. Dietary Life 20, 567-574.

4. Cho, H. S. and Kim, K. H. (2009) Assessment of quality characteristics of dried shrimp noodles for elderly foodservice operations. Korean J. Food Cook. Sci. 25, 267-274.

5. Chong, H. S. and Park, C. S. (2003) Quality of noodle added powder of Opuntia ficus-Indica var. Saboten. Korean J. Food Preserv. 10, 200-205.

6. Hwang, J. H. and Jang, M. S. (2001) Effect of paprika juice on the acceptability and quality of wet noodle (I). Korean $J$. Food Cook. Sci. 17, 373-379.

7. Kim, H. R., Hong, J. S., Choi, J. S., Han, G. J., Kim, T. Y., Kim, S. B., and Chun, H. K. (2005) Properties of wet noodle changed by the addition of Sanghwang Mushroom (Phellinus linteus) powder and extract. Korean J. Food Sci. Tech- nol. 37, 579-583.

8. Kim, J. G. and Shim, J. Y. (2006) Quality characteristics of wheat flour noodle added with onion powder. Food Eng. Prog. 10, 269-274.

9. Kim, S. K., Kim, H. R., and Bang, J. B. (1996) Effects of alkaline reagent on the rheological properties of wheat flour and noodle property. Korean J. Food Sci. Technol. 28, 58-65.

10. Kim, S. M. and Kim, E. J. (2009) Development of chicken breast noodles adding Rubus coreanum miquel and Opuntia ficus-indica var. saboten. J. Korean Soc. Food Sci. Nutr. 38, 1111-1117.

11. im, S. Y., Kang, M. Y., and Kim, M. H. (2008) Quality characteristics of noodle added with browned oak mushroom (Lentinus edodes). Korean J. Food Cook. Sci. 24, 665-671.

12. Kim, Y. A. (2002) Effects of mulberry leaves powder on the cooking characteristics of noodle. Korean J. Food Cook. Sci. 18, 632-636.

13. Kim, Y. S. (1998) Quality of wet noodle prepared with wheat flour mushroom powder. Korean J. Food Sci. Technol. 30, 1373-1380.

14. Lee, K. H. and Kim, K. T. (2000) Properties of wet noodle changed by the addition of whey powder. Korean J. Food Sci. Technol. 32, 1073-1078.

15. Lee, Y. C., Shin, K. A., Jeong, S. W., Moon, Y. I., Kim, S. D., and Han, Y. N. (1999) Quality characteristics of wet noodle added with powder of Opuntia ficus-indica. Korean J. Food Sci. Technol. 31, 1604-1612.

16. Lee, Y. S., Lim, N. Y., and Lee, K. H. (2000) A study on the preparation and evaluation of dried noodle products made from composite flours utilizing arrowroot starch. Korean $J$. Soc. Food Sci. 16, 681-688.

17. Oh, H. S. (2004) Biological activities of bamboo leaf and quality characteristics of buckwheat cold noodle using bamboo 
leaf powder as a functional ingredient. Korean J. Food Cook. Sci. 20, 498-504.

18. Park, B. H. and Cho, H. S. (2006) Quality characteristics of dried noodles made with Dioscorea japonica flour. Korean $J$. Food Cook. Sci. 22, 173-180.

19. Park, B. H., Jeon, E. R., Kim, S. D., and Cho, H. S. (2010) Quality characteristics of dried noodle added with lotus leaf powder. Korean J. Food Culture 25, 225-231.
20. Park, S. I. and Cho, E. J. (2004) Quality characteristics of noodle added with chlorella extract. Korean J. Food Nutr. 17, 120-127.

21. Sung, S. Y., Kim, M. H., and Kang, M. Y. (2008) Quality characteristics of noodle containing Pleurotus eryngii. Korean J. Food Cook. Sci. 24, 405-411.

(Received 2014.7.2/Revised 2014.10.13/Accepted 2014.10.16) 